\title{
Sustainability Assessment of the Groundwater Quality in the Western India to Achieve Urban
} Water Security

\section{Chitresh Saraswat $^{\mathrm{a}}$, Pankaj Kumar ${ }^{\mathrm{a}, \mathrm{b}^{*}}$, Prashant Bhalani ${ }^{\mathrm{c}}$}

a United Nations University - Institute for the Advanced Study of Sustainability, 4-53-70, Jingumae, Shibuya, Tokyo 150-8925, Japan,

b Natural Resources and Ecosystem Services, Institute for Global Environmental Strategies, Hayama, Kanagawa, Japan;

${ }^{\mathrm{c}}$ Institute of Science \& Technology for Advanced Studies \& Research, Sardar Patel University, Gujarat, India

*Corresponding Author - Pankaj Kumar- kumar@iges.or.jp

\section{$\underline{\text { ABSTRACT }}$}

Achieving water security and availability for all is the main agenda of the UN-Sustainable Development Goals by the year 2030. To achieve the goal of water secure future in rapidly urbanizing cities, the sustainable water supplies are necessary. In the western part of India, the city of Surat is continuously growing and rapidly urbanized, which exerting massive pressure on groundwater water supply to meet increasing water demands. The study adopted the investigative approach, in which a total 33 groundwater samples were collected in and around the city from open, bore and dug wells and hand pumps. The selection of sampling sites was based on the land use signature, areas with a different depth of aquifers and different geological formations. After the hydrogeochemical analysis, the study evaluated the present state of the groundwater quality and determined the spatial distribution of groundwater quality parameters such as hardness, electrical conductivity, $\mathrm{Cl}-, \mathrm{pH}, \mathrm{SO}_{4}{ }^{2-}$, and $\mathrm{NO}_{3}-$ concentrations. An interpolation technique, known as ordinary kriging, was used to acquire the spatial distribution of parameters of groundwater quality parameters. The result showed that the groundwater quality falls under class I (>25\%) and class II ( 25 to $75 \%$ ) category. The study recommends that the groundwater in the study area is not suitable for potable purposes, especially without any improved onsite water treatment facilities but it is appropriate for the irrigation purposes in City.

Keywords: Water Security, Water for all, Groundwater assessment, Groundwater quality, Water scarcity.

\section{Introduction}

On the earth, more than $96.5 \%$ of water is salt water stored in the form of the oceans and only $2.5 \%$ of freshwater is available for the human survival. In which the groundwater makes up $30.1 \%$ of the available freshwater, which is approximately $0.61 \%$ of the entire world water (Gleick, 2000; Tanvir, 2008). It is estimated that the total available groundwater is equal to the total fresh water available and stored in the form of ice and snow. This shows the importance of groundwater and relevance as 
natural storage that can buffer against shortages of surface water (Hassan, 2008). According to the United States geological survey states that there are about 4.2 million cubic kilometers of water within 0.8 kilometers of the planet's surface (Hinrichsen and Tacio, 2002). Every year due to the hydrological cycle, more than 500 thousand cubic kilometres of renewable freshwater shifts from oceans to the land through rain/snow but only $10 \%$ of which can be considered accessible for human use (Gleick, 2000). There is a strong linkage between freshwater and population, which is explained in figure 1 , the increase in population is directly proportional to the water demand (Vörösmarty et al., 2000). The factors responsible for water quality crisis and water scarcity, are constantly increasing water demands, population explosion, changes in land use, groundwater mining, pollution, deteriorating water quality and pollution from diffuse and local sources (Saraswat et al., 2016). Generally, both surface water and groundwater provide potable water, as long as it is treated sufficiently (Miller, 2006; Bauder et al., 2011). Groundwater is preferred over surface water because of its reliability during droughts or dry season, while surface water sources can deplete quickly. Also, as groundwater is less polluted, it is easier and cheaper to treat it in comparison with surface water. In present most of the people around the are sustaining on groundwater.

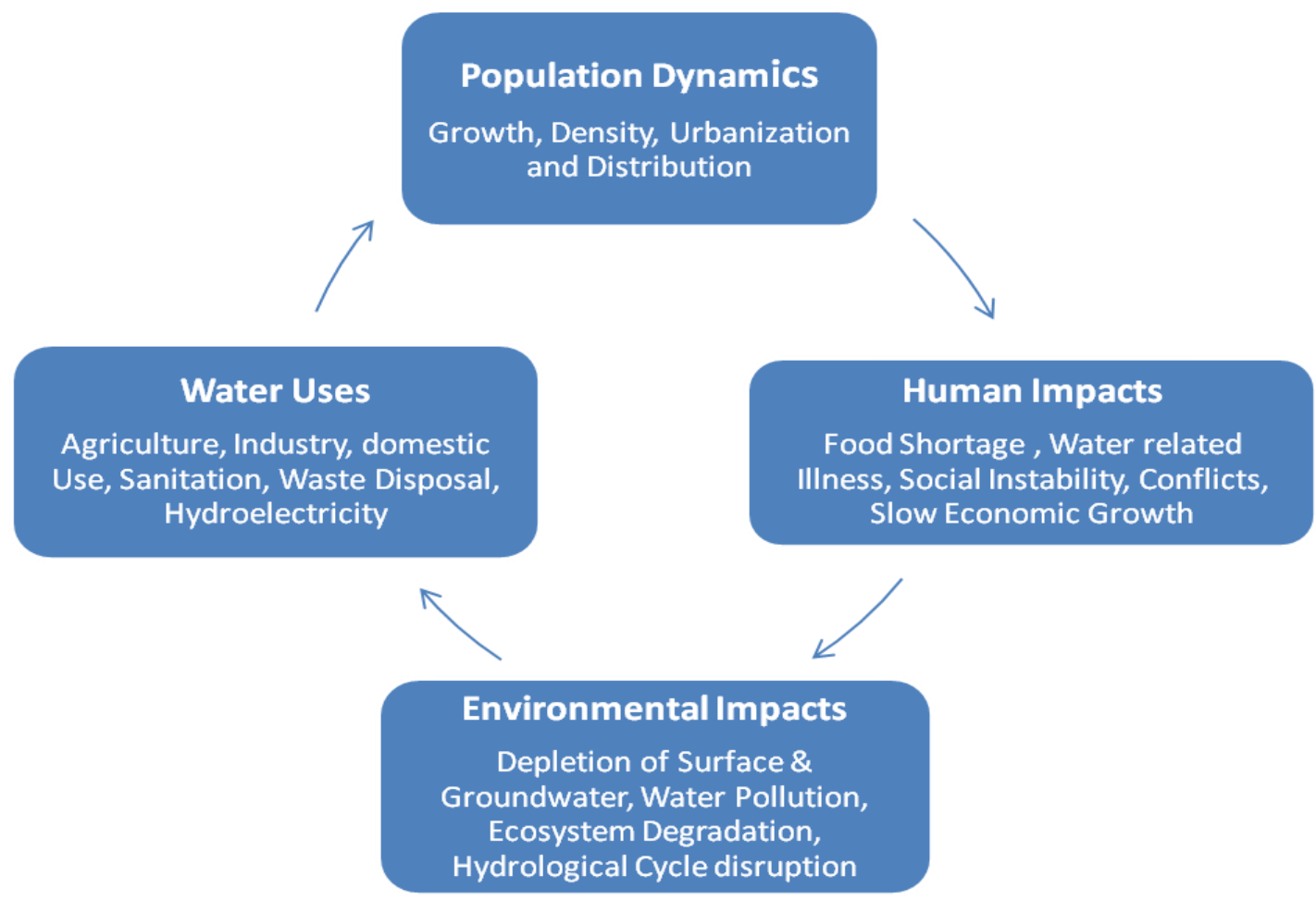

Figure 1: Dynamics of population, human health and freshwater impacts (Adapted from Gleick, 1993)

The groundwater usage is popular in comparison of surface water because of its wide availability and good quality, which can be adequately used for potable water supplies with very less or almost without treatment facilities. In India, around $80 \%$ of rural population and more than $50 \%$ of the urban population are directly dependent on groundwater for the domestic purpose (Biswas et al., 
2014). The possible uses of water are dependent on the trace elements available or found in groundwater. The hydrogeochemical process, which is taking place in aquifer system is responsible for the concentration of dissolved ions in groundwater (Mukherjee et al., 2015). To demonstrate the mechanism of groundwater evolution in any aquifer system, generally, the ionic ratios are used. Therefore, it is very important to analyze the hydrogeochemical characteristics of the aquifer in different seasons to understand the groundwater quality changes (Uddin et al., 2011). To study the groundwater quality changes various graphical methods and interpreting different indices are used (Srivastava and Ramanathan, 2008). In the composition, the saturation level of various minerals can give a signal of the vulnerability of the aquifers for future enrichment (Das et al., 2015; Das and Kumar, 2015). Although in major parts of India, the groundwater is drinkable and suitable for potable uses but due to contamination, various reports indicated the impact on human well being (Mahanta et al., 2015; Meliker et al., 2008). The extent of groundwater contamination problem is stern in Bangladesh and the eastern part of India, West Bengal, India (Ahmed et al., 2004; McArthur et al., 2004). After detection of groundwater contamination in various parts of India and Bangladesh, it is estimated that areas in eastern side of country and western Bangladesh, specifically region lie on and near Ganga, Meghna, Brahmaputra plains are at severe risk of groundwater contamination (Mukherjee et al., 2015; Singh et al., 2014; Nickson et al. 2007). The region with an area more than 570,000 square kilometer is home to more than 500 million population

The contamination in potable water is a major source of different kinds of skin problems ranging from hyper pigmentation (Kazi et al., 2009) and impose big health risk in many countries, especially developing countries. The potential impacts of groundwater contamination on human health and well being are severe from increased cancer risks to increased chronic (long-term) and acute (shortterm) noncancer health hazards. The groundwater contamination is found in a range of aquifers of unconsolidated sediment to bedrocks but it is analyzed that it is serious in unconsolidated sedimentary aquifers (Kumar et al., 2015; Smedley and Kinniburgh 2002). It is identified that the common mechanism responsible for groundwater contamination is is desorption from Fe-(hydro) oxides and reductive dissolution (Mukherjee et al., 2015; Kim et al. 2012). The degree of equilibrium between water and respective minerals are evaluated by saturation indexes (SI) (Das and Kumar, 2015) and the changes in saturation state help in distinguishing the different stages of hydrogeochemical analysis. The evolution helps to identify the important geochemical reactions leading to arsenic enrichment (Kumar et al., 2016; Coetsiers and Walraevens 2006). There is wide literature available on groundwater contamination in India, such as in the northeastern part of country, in different timeline various attempts are made to evaluate the interrelationship between groundwater quality parameters to understand the probable mechanism of groundwater contamination (Kumar et al., 2016; Mahanta et al., 2015, Radloff et al., 2011). The impact of groundwater contamination is severe on human well-being, it is explained in study by Goswami et al. (2014), the magnitude of human exposure in intermittent locations of Brahmaputra floodplain 
and impact on human well-being. The central Brahmaputra floodplain is a populated region and the health risk assessment is of urgent need but there is a huge gap in the literature on studies of hydrogeochemistry and health risk assessments together in the country. This research paper attempts to narrow this gap by tracing the responsible factors for groundwater geochemical evolution by evaluating the interrelationships between the key water quality parameters using multivariate statistical techniques and mineral saturation (usingPhreeqC) in western part of India

\section{Study Area}

The Surat city is playing a significant role in the upliftment of Indian economy, as the city is one of the most developed commercial city of Western part Gujarat state.The city has contributed more than 40 billion US dollars in the country's GDP. The city is also famous with the title of textile capital of the country and diamond capital of the world. The diamond business and real estate are new emerging businesses in the study area with $92 \%$ of the world's diamonds are cut and polished. The other major industries of the study area are steel production, petrochemical and Jari manufacturing (CDP, 2008). The study area is the 8th largest city in India and the 73rd largest urban area of the world. As per the census 2011, Surat city has a population of around 5 million and is expected to grow to 6.4 in the year 2021 and 8.5 million by the year 2031. The city growing at the decadal growth rate of more than $60 \%$ and is located on the bank of river Tapi in the southern zone of Gujarat state, India, an estuarian region and only $25 \mathrm{~km}$ away from the Arabian sea. The city experiences a tropical climate with a temperature rising above $40^{\circ} \mathrm{C}$ in summer and in between 12 to $15^{\circ} \mathrm{C}$ in winters. The city area is $335 \mathrm{sq} \mathrm{km}$ and located at $21^{\circ} 15^{\prime} \mathrm{N}$ latitudes and $72^{\circ} 52^{\prime} \mathrm{E}$ longitudes and covered by alluvial aquifer of medium to the coarse sandy soil. The elevation varies between 10 to $18 \mathrm{Mt}$ and the infrastructure includes a computerized water distribution and drainage system. The area of Surat city didn't increase significantly from 1688 to 1910, during 1990 to 2004 there was an increase in the area of city, moderately but after that from 2004 to 2013, Surat city area is expanded drastically because of rapid urbanization and industrialization which also indicate that there is demand on resources largely (CDP, 2008).

The study region can be divided into the coastal and alluvial region. In which, the coastal region represents the muddy shoreline with tidal flat stretch cut off by estuaries. The other one, the alluvial region is formed by river Tapi and distinguishes by flood plain of the river Tapi and Mindhola with a thick alluvial cover. The study area is dependent on river Tapi for meeting the water demands but rapid urbanization and industrialization impacted the water quality of the river, resulting in groundwater as an alternative and the main source of potable water in the region (CDP, 2008). During the many summer seasons, the drought and late onset of southwest monsoon already created the situations of water scarcity in the city. Various studies showed the negative impact on water supply and demand under the rapid economic and population growth in the city. For meeting the water demand of the future population of around 8 million people by the year 2020, it is estimated 
that minimum of $1200-1500$ MLD water is required to cater to rising water needs of the study area. Including water, for domestic use, additional water will be needed for the industrial purpose (Kapshe et al., 2013). This situation puts grave danger on the limited water resources system allocated to cater irrigation and power generation need of the city. With the business as usual scenario, it is imminent that study area will be water scarce in near future and there is huge need to understand the water allocation to manage the future water demands.

\section{Methodology}

In total 33 groundwater samples were collected from the bore, dug, open wells and hand pumps in the study area. The sampling sites are selected because of their different geological formations, land use signature, and depths of the aquifers. Using Global Positioning System (GPS III, Garmin), the sample coordinates were recorded and on-site measurements of the electrical conductivity (EC), temperature and $\mathrm{pH}$ were recorded using an inline flow cell ensuring the exclusion of atmospheric contamination and minimized fluctuations. The transportable "Orion Thermo water analyzing kit (Model Beverly, MA, 01915)" with a precision of 2\% was used for all kind of on-site measurements. Using the thoroughly rinsed polyethylene bottles the groundwater samples were collected from each location and filtered using $0.2 \mu \mathrm{m}$ Millipore membrane filters. The samples collected for major ions analysis were acidified using $1 \% \mathrm{HNO}_{3}$ to stabilize trace metals $(\mathrm{pH} 2$ ), while samples collected for nitrate were acidified with $\mathrm{H}_{3} \mathrm{BO}_{3}$. In an ice chest, all the samples were brought to the laboratory and stored at below $4^{\circ} \mathrm{C}$ temperature. The samples were analyzed for anion, cations and trace metals. The analysis of the concentration of $\mathrm{HCO}_{3}{ }^{-}$was analyzed by acid titration (using Metrohm Multi-Dosimat) while other anions $\mathrm{Cl}^{-}, \mathrm{NO}_{3}{ }^{-}, \mathrm{SO}_{4}{ }^{2-}, \mathrm{F}^{-}$and $\mathrm{PO}_{4}{ }^{3-}$ were analyzed by DIONEX ICS-90 ion chromatograph with an error percentage of less than $2 \%$, using duplicates. The trace elements and major cations are evaluated by inductively coupled plasma-mass spectrometry (ICP-MS) with a precision of less than2\%, using duplicates. For major ions, analytical precision was checked by the NICB, normalized inorganic charge balance (Kumar et al., 2010; Kumar et al., 2016). This is defined as $[(\mathrm{Tz}+-\mathrm{Tz}-) /(\mathrm{Tz}++\mathrm{Tz}-)]$ and signify the fractional difference between total cations and anions. The quality of the data points are supported by observed charge balance, which is better than $\pm 5 \%$ and generally this charge imbalance comes in favor of positive charge. In the study area, to understand the origin of groundwater mineralization the saturation index (SI) was calculated. Mineral saturation states with respect to selected minerals were computed as shown by equation (1), put forwarded by Garrels and Christ, 1965,

\section{$\mathrm{SI}=\log _{10}\left(K_{I A P} / K_{S P}\right)$ Eqn. (1)}

Where, SI $\rightarrow$ Saturation index,

$\mathrm{K}_{\mathrm{IAP}} \rightarrow$ Ion activity product of particular solid phase and 
$\mathrm{K}_{\mathrm{SP}} \rightarrow$ solubility product of the phase.

Based on the value of the SI, the saturation states were identified as oversaturated (precipitation; SI $>0$ ), saturated (equilibrium; $\mathrm{SI}=0$ ) and unsaturated (dissolution; $\mathrm{SI}<0$ ).

\section{Results and Discussion}

\subsection{Ground Water Chemistry}

The statistical summary of the chemical constituents of groundwater from the study area is shown in Table 1. The Table 1, explained the distribution pattern of average values of major cations and anions $(\mathrm{mg} / \mathrm{L})$ in groundwater. The results indicated the anionic abundance is in the order of $\mathrm{Cl}->$ HCO3- > SO42- > PO42- > NO3-, the high $\mathrm{Cl}-$ content signifies the impact of the coastal environment or local anthropogenic activities in the region. Another side, the results of cationic abundance found in the order of $\mathrm{Mg} 2+>\mathrm{Ca} 2+>\mathrm{Na}+>\mathrm{K}+>\mathrm{Fe}>\mathrm{Cr} 2+$, in which the higher content of $\mathrm{Mg} 2+$ is higher than $\mathrm{Ca} 2+$, which shows the effect of dolomite and limestone weathering. The result found that the $\mathrm{HCO} 3-$ and $\mathrm{Ca} 2+$ content are because of the carbonate weathering.

Table 1: The Statistical summary of groundwater chemical constituents

\begin{tabular}{|l|l|l|l|l|l|}
\hline Parameter & Unit & Average & Minimum & Maximum & SD \\
\hline $\mathrm{pH}$ & & 7.11 & 6.70 & 7.90 & 0.27 \\
\hline $\mathrm{EC}$ & $(\mu \mathrm{S} / \mathrm{cm})$ & 2647.53 & 1156.83 & 3478.12 & 781.50 \\
\hline TDS & $(\mathrm{mg} / \mathrm{L})$ & 1935.13 & 845.55 & 2542.22 & 571.21 \\
\hline Acidity & $(\mathrm{mg} / \mathrm{L})$ & 243.75 & 125.00 & 325.00 & 54.94 \\
\hline Alkality & $(\mathrm{mg} / \mathrm{L})$ & 180.00 & 100.00 & 300.00 & 54.77 \\
\hline TH & $(\mathrm{mg} / \mathrm{L})$ & 489.50 & 180.00 & 755.00 & 200.70 \\
\hline $\mathrm{Ca}^{2+}$ & $(\mathrm{mg} / \mathrm{L})$ & 174.38 & 65.00 & 340.00 & 77.78 \\
\hline $\mathrm{Mg}^{2+}$ & $(\mathrm{mg} / \mathrm{L})$ & 315.13 & 110.00 & 495.00 & 131.77 \\
\hline $\mathrm{K}^{+}$ & $(\mathrm{mg} / \mathrm{L})$ & 14.21 & 6.00 & 29.25 & 7.77 \\
\hline $\mathrm{Na}^{+}$ & $(\mathrm{mg} / \mathrm{L})$ & 100.89 & 64.90 & 115.38 & 14.50 \\
\hline $\mathrm{Cl}^{-}$ & $(\mathrm{mg} / \mathrm{L})$ & 438.69 & 62.04 & 1717.85 & 199.28 \\
\hline $\mathrm{HCO}_{3}^{-}$ & $(\mathrm{mg} / \mathrm{L})$ & 219.60 & 122.00 & 366.00 & 66.82 \\
\hline $\mathrm{SO}_{4}{ }^{2-}$ & $(\mathrm{mg} / \mathrm{L})$ & 80.01 & 21.25 & 115.78 & 28.03 \\
\hline $\mathrm{PO}_{4}{ }^{3-}$ & $(\mathrm{mg} / \mathrm{L})$ & 3.51 & 2.09 & 9.86 & 2.24 \\
\hline $\mathrm{NO}_{3}^{-}$ & $(\mathrm{mg} / \mathrm{L})$ & 0.23 & 0.09 & 0.42 & 0.11 \\
\hline $\mathrm{F}^{-}$ & $(\mathrm{mg} / \mathrm{L})$ & $\mathrm{BDL}$ & $\mathrm{BDL}$ & $\mathrm{BDL}$ & $\mathrm{BDL}$ \\
\hline
\end{tabular}

$\mathrm{BDL}=$ Below Detectable Limit

Table 1, indicated the $\mathrm{pH}$ values of ground water varied between into 6.7-7.9. In the different wells, there is no variation in $\mathrm{pH}$ found, which indicates that the groundwater is tapped from aquifers of 
single formations. The results indicated that there are $30 \%$ of groundwater samples have TDS beyond the limit and all the groundwater samples have EC beyond the limits (Table 2). Table 3, showed the suitability of groundwater for potable/ drinking purposes, analyzed that the $15 \%$ of samples fall in the poor category and $85 \%$ of the samples fall in the unacceptable category for drinking. Results showed that there is only $15 \%$ of samples falls in the category of fresh water and $85 \%$ of samples fall in the brackish water category. Total hardness of all samples ranged between 180-755 $\mathrm{mg} / \mathrm{L}$ and $65 \%$ samples have the hardness beyond the permissible limit. The sample 1 (S1) has the highest hardness that is $755 \mathrm{mg} / \mathrm{L}$. Table 2, analyzed that $30 \%$ of groundwater samples fall into the hard category and 70\% samples fall in the very hard category. Hardness doesn't mean that it poses a severe threat to health or well-being, in fact, the calcium and magnesium in drinking water ensure the average daily requirements of such these minerals in the diet. But in more quantity, the hard water can cause aesthetic problems and other difficulties. The Chloride is the most important parameter for determining salinization and the $15 \%$ of groundwater samples have the chloride beyond the limit, in the sample (S16), the amount of chloride is highest, around $717.85 \mathrm{mg} / \mathrm{L}$. The chloride is actively circulating at relatively shallow depths of ground water, which is derived from rain or nearer to coastlines. The continuous depletion of ground water along the coastal regions often leads to the movement of the saline sea water into fresh water wells spoiling their water quality. Referring to the recommended limit, it is found that all the samples have the amount of sulfate and nitrate under the required limit. Among cations, the range of permissible limit for $\mathrm{Ca}$ and $\mathrm{Mg}$ hardness prescribed by WHO is $200 \mathrm{mg} / \mathrm{l}$ and $150 \mathrm{mg} / \mathrm{l}$, respectively, but in the collected samples it is estimated as, Ca hardness is in the range of $65-340 \mathrm{mg} / \mathrm{l}$, and $\mathrm{Mg}$ hardness is in the range of $110-495 \mathrm{mg} / \mathrm{l}$. The $40 \%$ and $80 \%$ samples have the hardness beyond the permissible limit. The sources of calcium in groundwater is calcite, aragonite and gypsum and the source of is dolomites and mafic minerals in rocks. The solubility of dolomite in water is dependent on the composition. This concludes that the magnesium source is from the carbonate rock (limestone) deposited in the area which changes to dolomite due to the dissolution of calcium.

Table 2: Values for the drinking water with the percentage of samples beyond permissible limit (PL) and the resulting health implications (WHO, 2004) 


\begin{tabular}{|c|c|c|c|c|c|c|c|c|}
\hline \multirow{2}{*}{$\begin{array}{l}\text { Sr. } \\
\text { No }\end{array}$} & \multirow{2}{*}{ Parameter } & \multirow{2}{*}{ Unit } & \multicolumn{2}{|c|}{$\begin{array}{l}\text { WHO Standard } \\
(1994,2004)\end{array}$} & \multicolumn{2}{|c|}{$\begin{array}{l}\text { IS:10500:1991 } \\
\text { Standard }\end{array}$} & \multirow{2}{*}{$\begin{array}{ll}\% & \text { of } \\
\text { Sample } \\
\text { beyond } \\
\text { Limit }\end{array}$} & \multirow[t]{2}{*}{ Effects } \\
\hline & & & $\begin{array}{l}\text { Desirable } \\
\text { Limit } \\
\text { (D.L) } \\
\end{array}$ & $\begin{array}{l}\text { Permissible } \\
\text { Limit (P.L) }\end{array}$ & $\begin{array}{l}\text { Desirable } \\
\text { Limit } \\
\text { (D.L) }\end{array}$ & $\begin{array}{l}\text { Permissible } \\
\text { Limit (P.L) }\end{array}$ & & \\
\hline 1 & $\mathrm{P}^{\mathrm{H}}$ & -- & $7-8.5$ & 9.2 & $6.5-8.5$ & $\begin{array}{c}\text { No } \\
\text { relaxation }\end{array}$ & 0 & $\begin{array}{c}\text { Bitter } \\
\text { taste, } \\
\text { Mucous } \\
\text { membrane }\end{array}$ \\
\hline 2 & $\mathrm{EC}$ & $(\mu \mathrm{S} / \mathrm{cm})$ & 500 & 1400 & 500 & 1000 & 85 & $\begin{array}{l}\text { Gastro- } \\
\text { intestinal } \\
\text { irritation }\end{array}$ \\
\hline 3 & TDS & $(\mathrm{mg} / \mathrm{L})$ & -- & -- & 500 & 2000 & -- & $\begin{array}{c}\text { Undesired } \\
\text { taste, } \\
\text { Gastro- } \\
\text { intestinal } \\
\text { irritation } \\
\end{array}$ \\
\hline 4 & $\mathrm{TH}$ & $(\mathrm{mg} / \mathrm{L})$ & 100 & 500 & 300 & 600 & 65 & $\begin{array}{c}\text { Scale } \\
\text { formation }\end{array}$ \\
\hline 5 & $\mathrm{Ca}^{2+}$ & $(\mathrm{mg} / \mathrm{L})$ & 75 & 200 & 75 & 200 & 40 & $\begin{array}{c}\text { Scale } \\
\text { formation } \\
\end{array}$ \\
\hline 6 & $\mathrm{Mg}^{2+}$ & $(\mathrm{mg} / \mathrm{L})$ & 50 & 150 & 30 & 100 & 80 & $\begin{array}{c}\text { Encrustatio } \\
\mathrm{n} \text { in water } \\
\text { supply } \\
\text { structure }\end{array}$ \\
\hline 7 & $\mathrm{~K}^{+}$ & $(\mathrm{mg} / \mathrm{L})$ & -- & 200 & -- & 200 & 0 & $\begin{array}{c}\text { Interfere } \\
\text { with nerve } \\
\text { impulse } \\
\end{array}$ \\
\hline 8 & $\mathrm{Na}^{+}$ & $(\mathrm{mg} / \mathrm{L})$ & -- & 200 & -- & -- & 0 & $\begin{array}{c}\text { Scale } \\
\text { formation } \\
\end{array}$ \\
\hline 9 & $\mathrm{Fe}$ & $(\mathrm{mg} / \mathrm{L})$ & -- & 0.1 & -- & 0.3 & 100 & \begin{tabular}{|c|}
$\begin{array}{c}\text { Promotes } \\
\text { bacterial } \\
\text { growth }\end{array}$ \\
\end{tabular} \\
\hline 10 & $\mathrm{Cl}^{-}$ & $(\mathrm{mg} / \mathrm{L})$ & 200 & 600 & 250 & 1000 & 15 & Salty taste \\
\hline 11 & $\mathrm{SO}_{4}{ }^{2-}$ & $(\mathrm{mg} / \mathrm{L})$ & 200 & 400 & 200 & 400 & 0 & $\begin{array}{l}\text { Laxative } \\
\text { effects }\end{array}$ \\
\hline 12 & $\mathrm{NO}_{3}^{-}$ & $(\mathrm{mg} / \mathrm{L})$ & -- & 45 & 45 & 100 & 0 & $\begin{array}{c}\text { Methanogl } \\
\text { obinemia }\end{array}$ \\
\hline
\end{tabular}

Results for sodium and potassium in the samples, found under recommended limit, except a few.

The reason for the higher concentration of potassium in groundwater could be fertilizer used for farming and it is penetrated into groundwater. Results for iron, as trace metal, showed that in all the samples the concentration of iron is higher than the desirable limit $(0.3 \mathrm{mg} / \mathrm{l})$. This is important 
because of its adverse effect on domestic uses and water supply structures, and promotion in iron bacteria.

Table 3: Suitability of Groundwater for drinking Purposes

\begin{tabular}{|c|c|c|}
\hline Parameter & Water Class & \% of Sample \\
\hline \multicolumn{3}{|l|}{ TDS } \\
\hline$<300$ & Excellent & NIL \\
\hline $300-600$ & Good & NIL \\
\hline $600-900$ & Fair & NIL \\
\hline $900-1,200$ & Poor & 15 \\
\hline$>1,200$ & Unacceptable & 85 \\
\hline \multicolumn{3}{|c|}{ Based on total hardness as CaCO3 (mg/l) after Sawyer and Mc Cartly (1967) } \\
\hline$<75$ & Soft & NIL \\
\hline $75-150$ & Moderately hard & NIL \\
\hline $150-300$ & Hard & 30 \\
\hline$>300$ & Very hard & 70 \\
\hline \multicolumn{3}{|c|}{ Nature of groundwater based on TDS (mg/l) values } \\
\hline $0-1000$ & Fresh & 15 \\
\hline $1001-10000$ & Brackish & 85 \\
\hline $10001-100000$ & Salty & NIL \\
\hline$>100000$ & Brine & NIL \\
\hline
\end{tabular}

\subsection{Hydrogeochemical Evolutionary Processes}

The graphical representation of scatter plots for hydrogeochemical evolutionary process are shown in figures 2, 3 and 4. In figure 2(a), the graph of $\mathrm{Tz}+$ versus $\mathrm{Na}++\mathrm{K}+$ showed that all the sample points are in favor of $\mathrm{Tz}+$, which suggest that sodium and potassium are not dominant in groundwater samples. Another cationic activity is also present rather than sodium and potassium, which also indicated that there will be no agricultural impact on groundwater. The graphical representation of $\mathrm{Tz}+$ versus $\mathrm{Ca} 2++\mathrm{Mg} 2+$, in figure 2 (b), showed that all the samples fall near to (1:1) equiline, it means $\mathrm{Tz}+$ concentration due to dominance of $\mathrm{Ca} 2++\mathrm{Mg} 2+$ which implies that source of calcium and magnesium are from carbonate weathering and most potential minerals suggested to be calcite and dolomite. In figure 2 (c), the graphical representation of HCO3- versus $\mathrm{Ca} 2++\mathrm{Mg} 2+$ showed that the $\mathrm{Ca} 2++\mathrm{Mg} 2+>\mathrm{HCO} 3-$ relation, suggesting that additional $\mathrm{Ca} 2+$ $+\mathrm{Mg} 2+$ are coming from muscovite, illite, calcium hydroxide (lime) weathering other than that of limestone. In figure 2 (d), the graphical representation of versus $\mathrm{HCO} 3-+\mathrm{SO} 42-$ versus $\mathrm{Ca} 2++$ $\mathrm{Mg} 2+$, showed that all the sample points are above equiline representing that there is the enrichment 
of $\mathrm{Ca} 2++\mathrm{Mg} 2+$ over HCO3- + SO42- which implies that the dissolution of calcite is abundant in the sand. It was found that $\mathrm{Mg} 2+$ and $\mathrm{Ca} 2+$ are first and second dominant ion in all cation concentration, whereas HCO3- is second dominant ion in the total anion. The extent of contamination is further examined by the graph in figure 3(a), HCO3-versus Tz+ plot. The results showed that all the samples points occupy the area above equiline and closer to the $y$-axis, which confirms that water chemistry of the area is also influenced by a secondary process such as anthropogenic activity. In figure 3(b), the plot represents that the most of the groundwater samples are in a relation of $\mathrm{Cl}->\mathrm{Na}+$, meaning the existence of salinization. The category-I, the abnormal higher value of $\mathrm{Cl}$ - can be attributed to the surface sources through the leaching from domestic wastewaters, septic tanks, and animal waste. Category II shows the migration path of change in water quality and while category III, occupies very few samples clearly demonstrate cumulative effect of salt water up-coming because of the high extraction rate supported by slight mixing of fresh water and salt water. In figure 3 (c), the scatter plot between $\mathrm{Na}++\mathrm{K}+$ and $\mathrm{Cl}-\mathrm{SO}_{4}{ }^{2-}$ that clearly showed that the presence of secondary salinity source in the aquifer system. The main driving factors are degradation of organic matter and sewage. In figure 3 (d), the comparison of the sulfate and calcium contents showed, it was found that all the samples show the relation of $\mathrm{Ca} 2+>\mathrm{SO} 42-$ indicate that calcium source of ground water is from calcite, dolomite or silicate minerals like feldspar rather than gypsum. 
A)

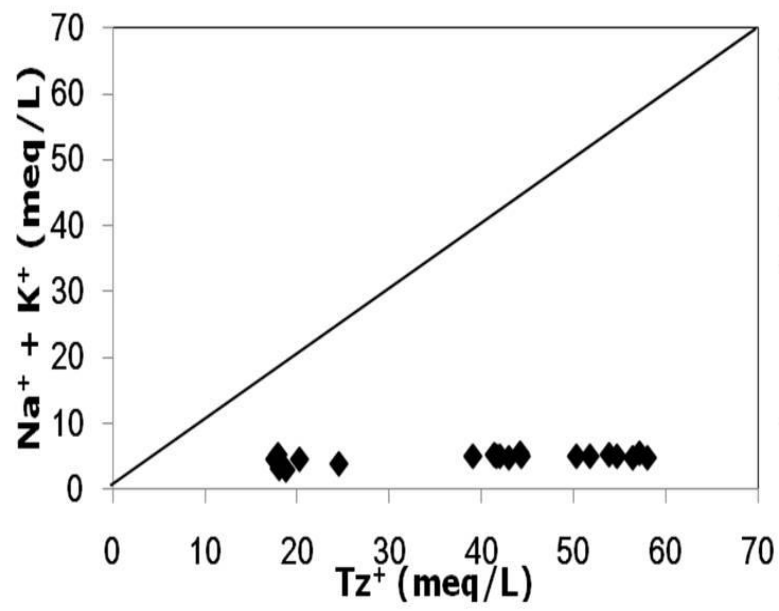

C)

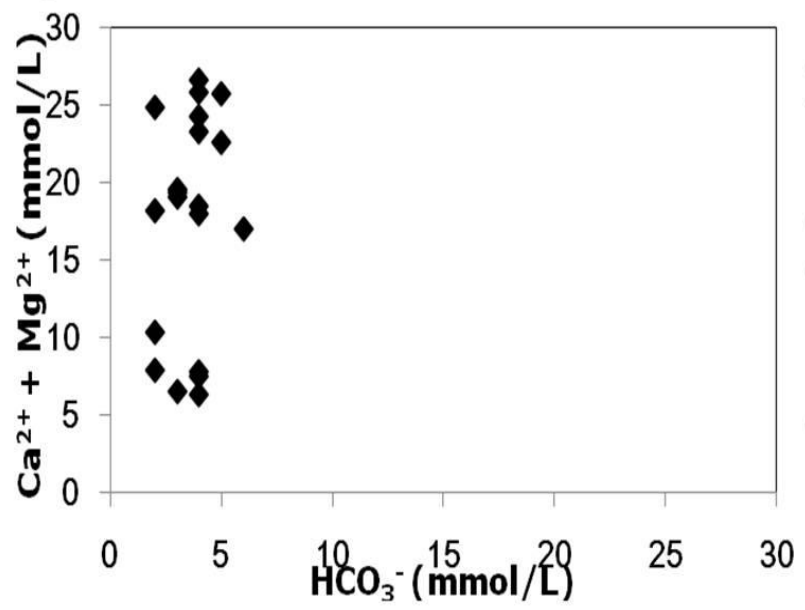

B)

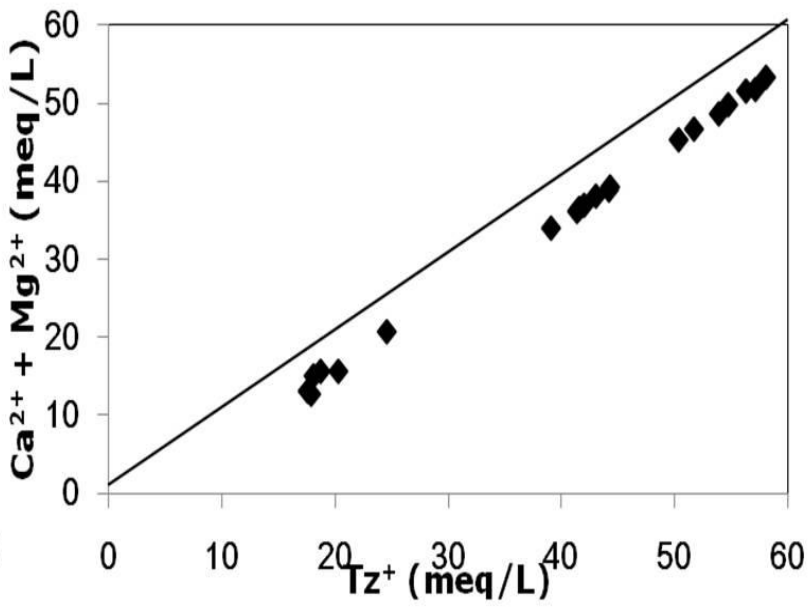

D)

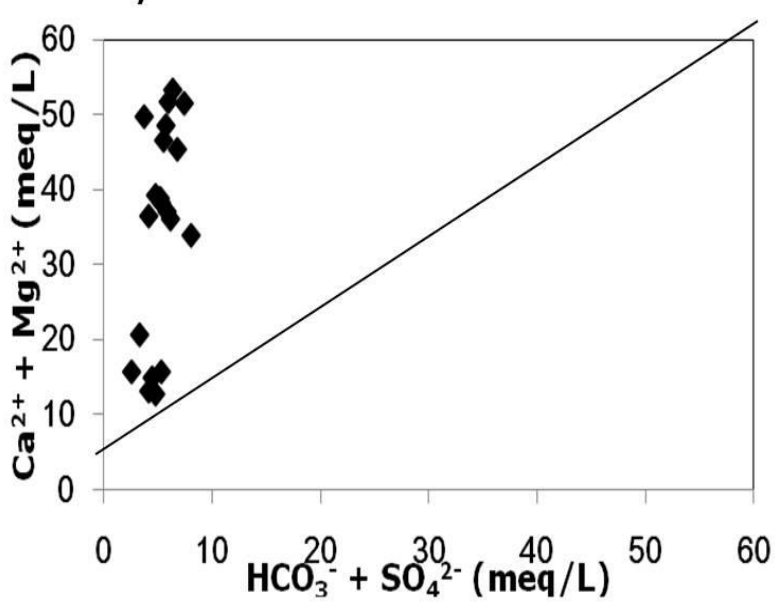

Figure 2: Scatter plot for Hydrogeochemical Evolutionary Process, (A) Scatter plot between $\mathrm{Tz}^{+}$and $\mathrm{Na}^{+}+\mathrm{K}^{+}$, (B) Scatter plot between $\mathrm{Tz}^{+}$and $\mathrm{Ca}^{2+}+\mathrm{Mg}^{2+}$, (C) Scatter plot between $\mathrm{HCO}_{3}{ }^{-}$and $\mathrm{Ca}^{2+}$ $+\mathrm{Mg}^{2+}$, (D) Scatter plot between $\mathrm{Ca}^{2+}+\mathrm{Mg}^{2+}$ and $\mathrm{HCO}_{3}{ }^{-}+\mathrm{SO}_{4}{ }^{2-}$ 
A)

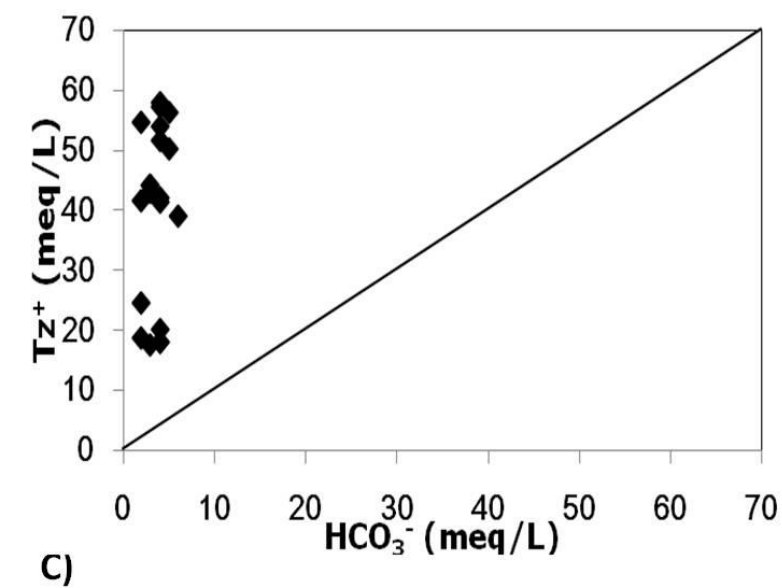

C)

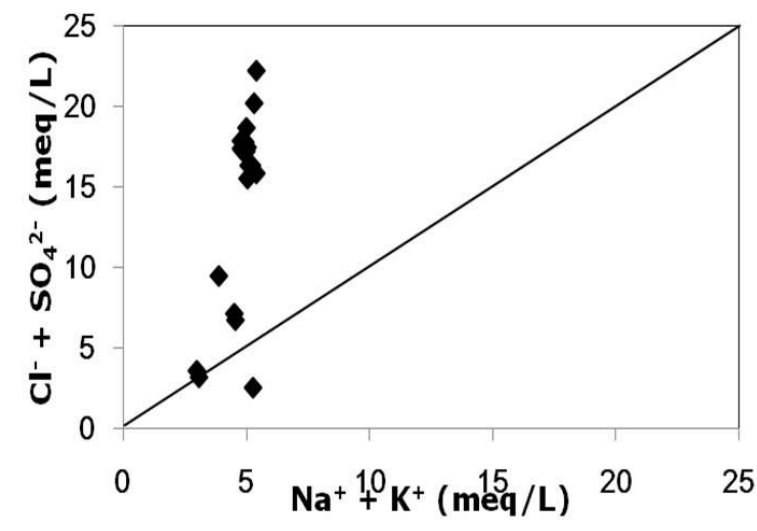

B)

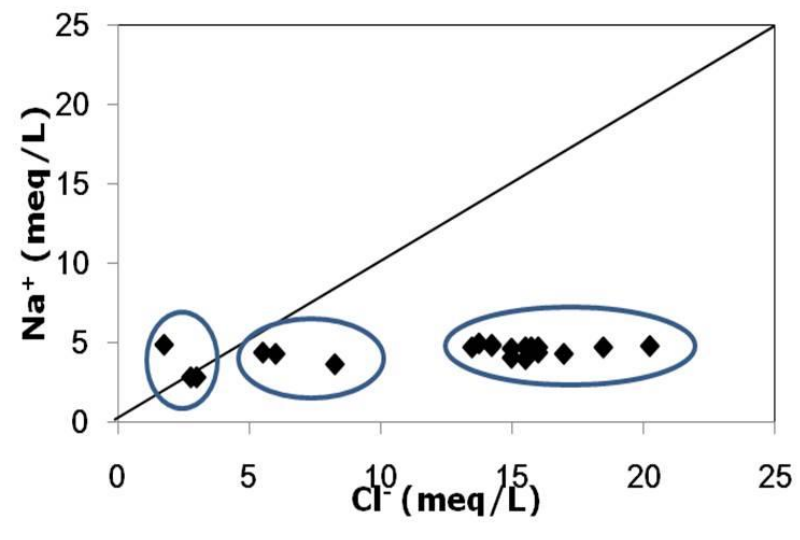

D)

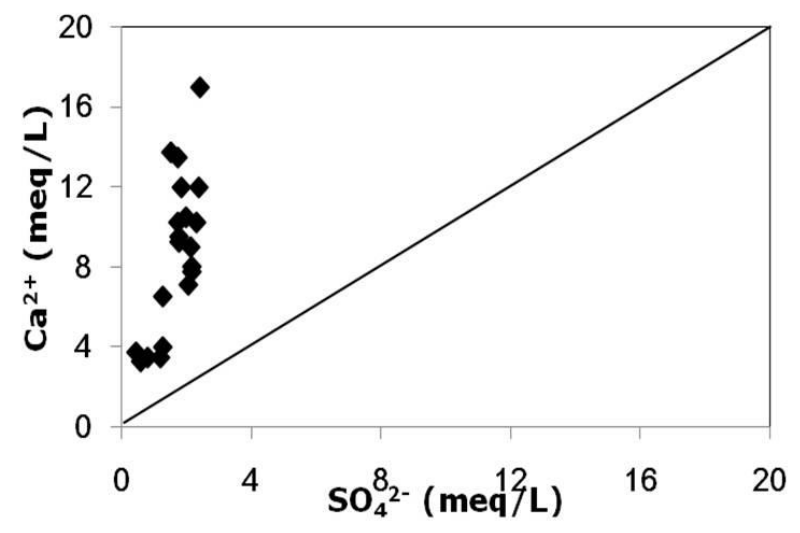

Figure 3: Scatter Plots for Hydrogeochemical Evolutionary Processes, (A) Scatter plot between $\mathrm{HCO}_{3}{ }^{-}$and $\mathrm{Tz}^{+}$, (B) Scatter plot between $\mathrm{Cl}^{-}$and $\mathrm{Na}^{+}$, (C) Scatter plot between $\mathrm{Na}^{+}+\mathrm{K}^{+}$and $\mathrm{Cl}^{-}+$ $\mathrm{SO}_{4}{ }^{2-}$, (D) Scatter plot between $\mathrm{SO}_{4}{ }^{2-}$ and $\mathrm{Ca}^{2+}$

In figure 4 (a), the plot of $\mathrm{Cl}-$ versus $\mathrm{Ca} 2++\mathrm{Mg} 2+(\mathrm{mmol} / \mathrm{L})$ indicates the $\mathrm{Ca}$ and $\mathrm{Mg}$ increased with salinity, which could be indication of absence of greater anionic exchange through natural inert resin like clay and weathered rock and in figure 4 (b), the graphical representation of $\mathrm{Cl}$ - versus $\mathrm{Na}++\mathrm{K}+$, showed that most of the sampling point falls below equiline which indicated that $\mathrm{Cl}$ may derive from the human activities, use of fertilizer, road salt, animal wastes and some of the samples falls near to equiline which indicate that coastal environmental effect and few sample fall in intermediate category which indicate that water will be salinized near future. In figure 4 (c), showed, that the molar ratio of $\mathrm{Na} / \mathrm{Cl}$ for ground water samples for study area generally range in 0.2 to 2.7. As most of the samples have $\mathrm{Na} / \mathrm{Cl}$ ratio below one which implies it's not solely because of ground water salinization rather than geochemical processes operating at local scale. 
A)

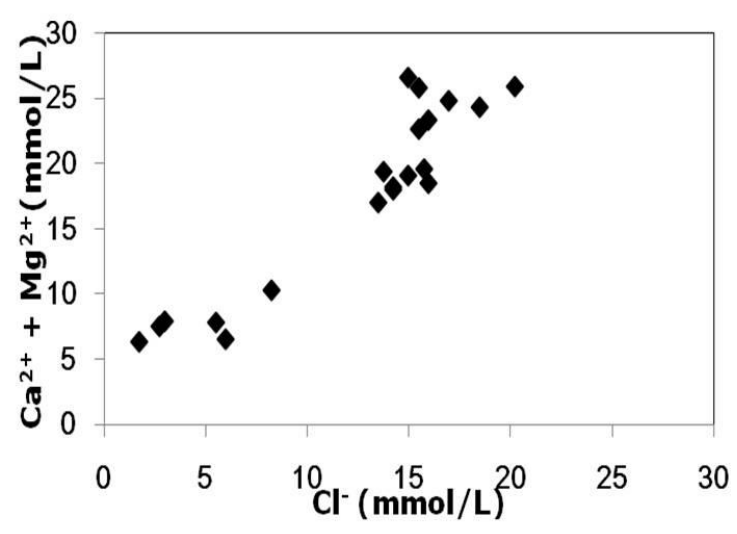

B)

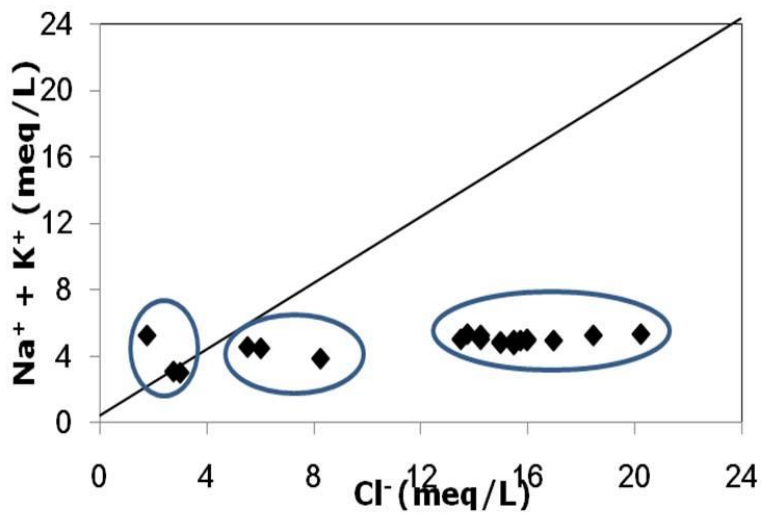

C)

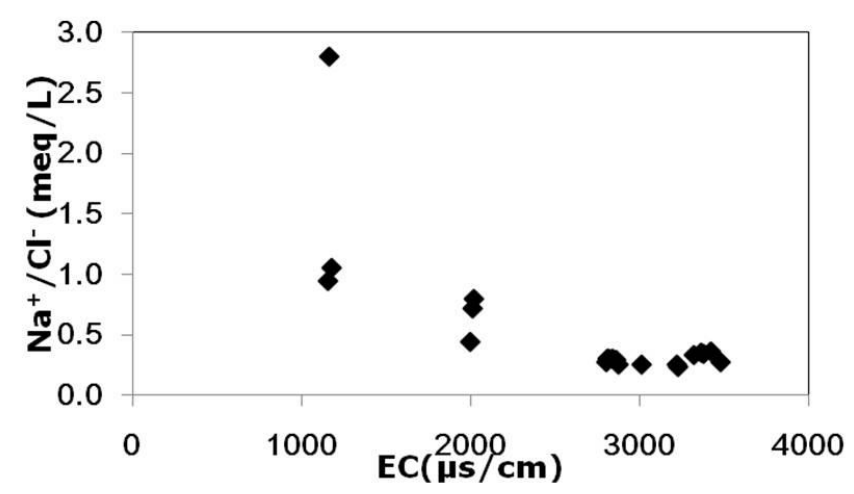

Figure 4: Scatter Plots for Hydrogeochemical Evolutionary Processes, (A) Scatter plot between $\mathrm{Cl}^{-}$ and $\mathrm{Ca}^{2+}+\mathrm{Mg}^{2+}$, (B) Scatter plot between $\mathrm{Cl}^{-}$and $\mathrm{Na}^{+}+\mathrm{K}^{+}$, (C) Scatter plot between EC and $\mathrm{Na}^{+} / \mathrm{Cl}^{-}$

\subsection{Assessment Of Groundwater Quality for Irrigation Use}

Groundwater is confined to coastal alluvium and its suitability for irrigation is assessed by considering salinity, chlorinity and sodicity apart from other parameters (Mills, 2003; Nishanthiny et al., 2011). In table 4, the water salinity measured with respect to EC, $60 \%$ of samples falls in slight to moderate $(700-3,000 \mu \mathrm{S} / \mathrm{cm})$ and $40 \%$ samples are in a severe category $(>3,000 \mu \mathrm{S} / \mathrm{cm})$ and The water salinity measured with respect to TDS, $30 \%$ of samples fall into slight to moderate $(450-2000 \mathrm{mg} / \mathrm{L})$ and $70 \%$ samples are in the severe category $(>2,000 \mathrm{mg} / \mathrm{L})$.

Table 4: Evaluation of the Suitability of groundwater samples for irrigation (Guidelines adapted from Pettygrove and Asano, 1985; Ayers and Westcot, 1985; Metcalf and Eddy, 2003)

\begin{tabular}{|c|c|c|c|c|c|}
\hline \multirow[t]{2}{*}{ Potential irrigation problem } & \multicolumn{2}{|c|}{ Degree of restriction on use } & \multicolumn{3}{|c|}{$\%$ of sample } \\
\hline & None(N) & $\begin{array}{lll}\text { Slight } & \text { to } & \text { Severe }(\mathrm{S}) \\
\text { moderate}(S-M) & & \end{array}$ & $\mathrm{N}$ & S-M & $\mathrm{S}$ \\
\hline
\end{tabular}




\begin{tabular}{|c|c|c|c|c|c|c|}
\hline \multicolumn{7}{|c|}{ Salinity (affects crop water availability) } \\
\hline $\mathrm{EC}(\square \mathrm{S} / \mathrm{cm})$ & $<700$ & $700-3000$ & $>3000$ & NIL & 60 & 40 \\
\hline $\mathrm{TDS}(\mathrm{mg} / \mathrm{L})$ & $<450$ & $450-2000$ & $>2000$ & NIL & 30 & 70 \\
\hline \multicolumn{7}{|c|}{ Permeability (affects infiltration rate of water into the soil) } \\
\hline $\mathrm{SAR}=0-3$ & $\mathrm{EC}>700$ & $700-200$ & $<200$ & NIL & NIL & NIL \\
\hline $3-6$ & 1200 & $1200-300$ & $<300$ & 25 & NIL & NIL \\
\hline $6-12$ & 1900 & $1900-500$ & $<500$ & 60 & 15 & NIL \\
\hline $12-20$ & 2900 & $2900-1300$ & $<1300$ & NIL & NIL & NIL \\
\hline \multicolumn{7}{|c|}{ Specific Ion toxicity (affects sensitive crop) } \\
\hline \multicolumn{7}{|l|}{ (Sodium) $\mathrm{Na}^{+}$} \\
\hline Surface Irrigation & $\mathrm{SAR}<3$ & $3-9$ & $>9$ & NIL & 85 & 15 \\
\hline Sprinkler irrigation $(\mathrm{mg} / \mathrm{l})$ & $<70$ & $>70$ & -- & 10 & 90 & -- \\
\hline \multicolumn{7}{|l|}{$\mathrm{Cl}^{-}(\mathrm{mg} / \mathrm{l})$} \\
\hline Surface Irrigation & $<140$ & $140-350$ & $>350$ & 15 & 15 & 70 \\
\hline Sprinkler irrigation & $<100$ & $>100$ & -- & NIL & 100 & -- \\
\hline \multicolumn{7}{|c|}{ Miscellaneous effects (affect susceptible crops) } \\
\hline Overhead Sprinkling only & & & & & & \\
\hline $\mathrm{HCO}_{3}^{-}(\mathrm{mg} / \mathrm{l})$ & $<90$ & $90-500$ & $>500$ & NIL & 100 & NIL \\
\hline
\end{tabular}

* Figures are in percentage of samples in the particular categories are evaluated using EC and SAR of the groundwater

The soil permeability reduces due to the excessive sodium content relative to the calcium and magnesium and thus restrain the supply of water needed for the crops. All the water samples fall in the excellent category, which is good for irrigation on every kind of soils. Based on SAR, the degree of restriction on the use of water for irrigation with respect to EC is shown in Table 4.

The results showed (Table 6), that no single sample of groundwater is in the permissible, doubtful or unsuitable category. Interestingly, all samples fall in safe water class (classifications by Eaton (1950) and Wilcox (1955)). The classification is helpful in understanding the criteria for quality of different types of irrigation water. The $\mathrm{Na} \%$ indicates, that the groundwater is excellent to good for irrigation. The higher concentration of sodium in irrigation water displace the $\mathrm{Mg} 2+$ and $\mathrm{Ca} 2+$ ions and tends to be absorbed by clay particles. This exchange process of $\mathrm{Na}+$ in water for $\mathrm{Ca} 2+$ and $\mathrm{Mg} 2+$ in the soil decrease the permeability and results in soil with poor internal drainage.

Table 5: Statistical Summaries of Chemical Data of Groundwater Samples, Surat

\begin{tabular}{|l|l|l|l|l|l|}
\hline Parameter & Unit & Average & Minimum & Maximum & SD \\
\hline SAR & & 6.90 & 4.75 & 11.86 & 1.78 \\
\hline \% Na & \% & 13.76 & 8.25 & 29.33 & 5.83 \\
\hline
\end{tabular}




\begin{tabular}{|l|l|l|l|l|l|}
\hline PI & \% & 18.42 & 10.47 & 38.45 & 8.27 \\
\hline Mg/Ca & & 1.85 & 1.22 & 2.36 & 0.39 \\
\hline Mg ratio & & 64.28 & 54.97 & 70.21 & 5.04 \\
\hline CAI-1 & & 0.60 & -1.04 & 0.81 & 0.42 \\
\hline CAI-2 & & 1.07 & -0.23 & 2.33 & 0.64 \\
\hline
\end{tabular}

The soil permeability is affected by long-term irrigation influenced by $\mathrm{Na}^{+}, \mathrm{Ca}^{2+}, \mathrm{Mg}^{2+}$ and $\mathrm{HCO}_{3}^{-}$ contents and permeability index (PI) values indicates the suitability of groundwater for irrigation purposes. The PI ranged from 10.46 to $38.44 \%$ with the average value of $18.41 \%$ (Table 5). Based on WHO criterion for assessing the suitability of water for irrigation based on the permeability index (WHO, 1993; WHO 2004), the permeability index values for $80 \%$ of the groundwater samples fall under class I (PI in range of 1 to 24\%) and $20 \%$ of the sample falls under class II category (PI ranged in 25 to $75 \%$ ).

Table 6: Suitability of Groundwater for Irrigation

\begin{tabular}{|c|c|c|}
\hline Parameter & Water Class & \% of Sample \\
\hline \multicolumn{3}{|l|}{$\mathrm{EC}(\mu \mathrm{S} / \mathrm{cm})$} \\
\hline$<250$ & Excellent & NIL \\
\hline $250-750$ & Good & NIL \\
\hline $750-2000$ & Permissible & NIL \\
\hline $2000-3000$ & Doubtful & 20 \\
\hline$>3000$ & Unsuitable & 80 \\
\hline \multicolumn{3}{|c|}{ Based on alkalinity hazard (SAR) after Richards (1954) } \\
\hline$<10$ & Excellent & 100 \\
\hline $10-18$ & Good & NIL \\
\hline $18-26$ & Doubtful & NIL \\
\hline$>26$ & Unsuitable & NIL \\
\hline \multicolumn{3}{|c|}{ Based on percent Sodium after Wilcox (1955) } \\
\hline$<20$ & Excellent & 85 \\
\hline $20-40$ & Good & 15 \\
\hline $40-60$ & Permissible & NIL \\
\hline $60-80$ & Doubtful & NIL \\
\hline$>80$ & Unsafe & NIL \\
\hline \multicolumn{3}{|c|}{$\% \mathrm{Na}$ (Eaton 1950) } \\
\hline$>60$ & Safe & 100 \\
\hline$<60$ & Unsafe & NIL \\
\hline
\end{tabular}




\begin{tabular}{|l|l|l|}
\hline Based on residual Mg/Ca ratio & 20 \\
\hline$<1.5$ & Safe & 80 \\
\hline $1.5-3$ & Moderate & NIL \\
\hline$>3$ & Unsafe & \\
\hline
\end{tabular}

It is significant to understand the groundwater chemical composition changes during the sub-surface travel. The Chloro-alkaline indices CAI 1 and CAI 2 are recommended by Schoeller, 1977), which specifies that the ion exchange between the groundwater and the host environment. The ion exchange of $\mathrm{Na}^{+}$and $\mathrm{K}^{+}$from water with magnesium and calcium in the rock meaning that the exchange is direct and the indices are positive and otherwise, the exchange is indirect and indices are negative.It has been observed that $80 \%$ of samples show positive ratios and only $10 \%$ of samples show negative ratios, there is no strong indirect exchange was present. In most of the waters, the calcium and magnesium maintain a state of equilibrium. The more amount of $\mathrm{Mg}^{2+}$ in the water adversely affect the soil quality and results in decreased crop yields. The results found that all samples have magnesium ratio more than 50\%. The magnesium deteriorates soil structure, particularly when waters are sodium dominated and highly saline. The $\mathrm{Mg} / \mathrm{Ca}$ ratio can classify suitability of water for irrigation purposes and analysis results evaluated that $20 \%$ of groundwater samples fall in the safe category and $80 \%$ falls in the moderate category. This indicates the high suitability of groundwater for irrigation purposes (Table 6).

\subsection{Groundwater Hydrochemical Facies}

Plotting the concentrations of major cations and anions in tri linear diagram, suggested by Piper, 1994, the is helpful in analyzing the geochemical evolution of groundwater. Using the "Aquachem software", Piper diagram plotted and Figure 5 showed that the $90 \%$ of the groundwater samples are in the category of $\mathrm{Mg}-\mathrm{Cl}$ type of water, which indicates the water affected by carbonate hardness and salinity and other $10 \%$ of the samples fall in $\mathrm{Mg}-\mathrm{HCO}_{3}$. 


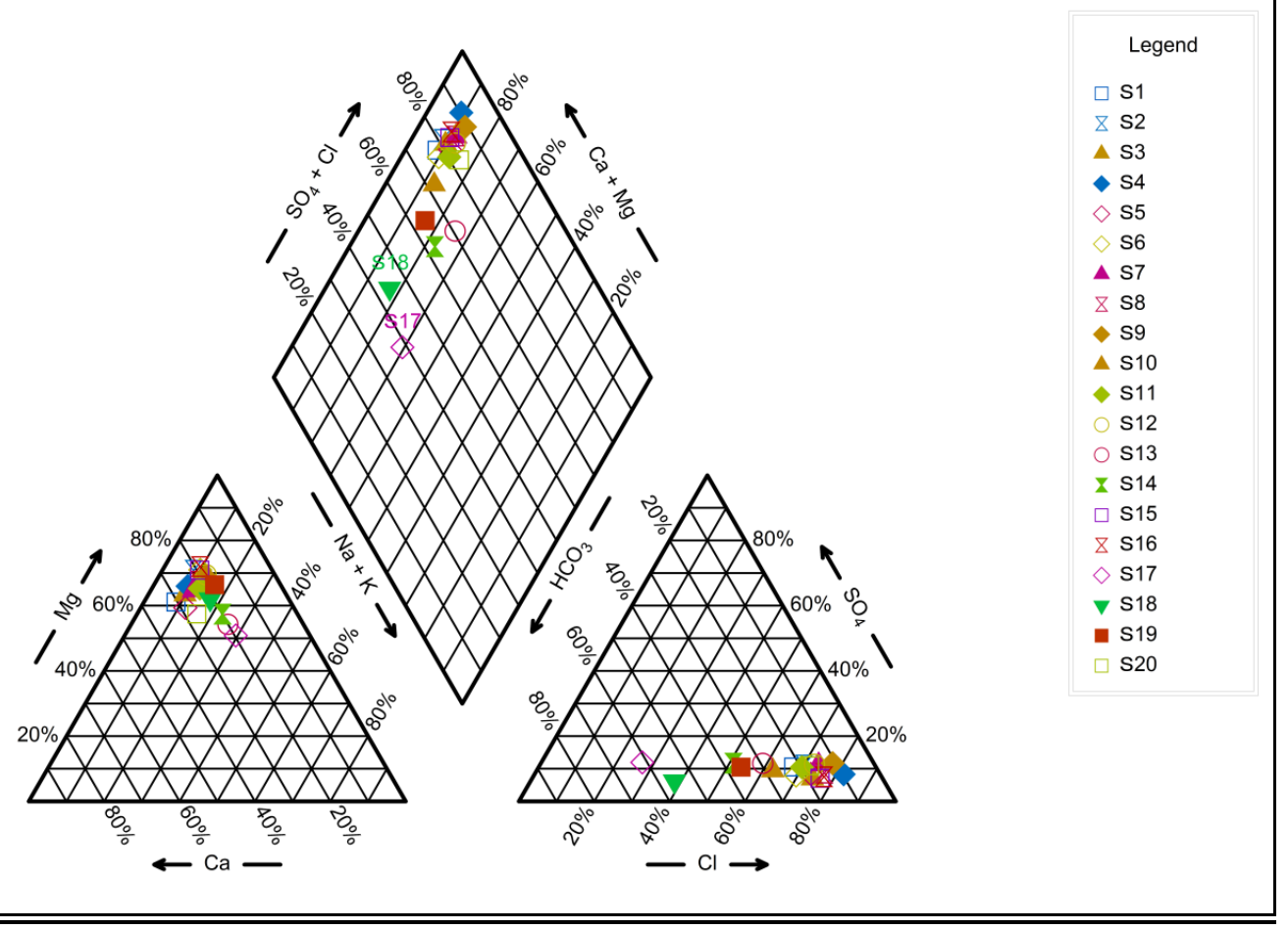

Figure 5: Piper diagram showing ground water quality for the Study Area

In Figure 6, the major ion plotted in showed that the lateral distribution of select ions and the milliequivalent concentration of ions $\left(\mathrm{Ca}^{2+}, \mathrm{Mg}^{2+}, \mathrm{Cl}^{-}, \mathrm{SO}_{4}{ }^{2-}, \mathrm{Na}^{+}, \mathrm{K}^{+}\right.$, and $\left.\mathrm{HCO}_{3}{ }^{-}\right)$ranges between 0.5 and $30 \mathrm{meq} / \mathrm{L}$. Generally, water with high $\mathrm{Mg}$ content with also has high $\mathrm{Cl}$ content. The high $\mathrm{Mg}$ is of two types, one with $\mathrm{Cl}$ in the range 1.8-21 meq/L, known as $\mathrm{Mg}-\mathrm{Cl}$ and another with $\mathrm{HCO}_{3}$ is in the range of 2-7 meq/L, known as $\mathrm{Mg}-\mathrm{HCO}_{3}$. The results evaluated that in the study region the salinization and mineralization phenomena are active and from the (Figure 7) Durov plot it is analyzed that all samples have a high TDS with $\mathrm{Mg}$ as dominant cation and $\mathrm{Cl}$ as a dominant anion in ground water of the study area. 


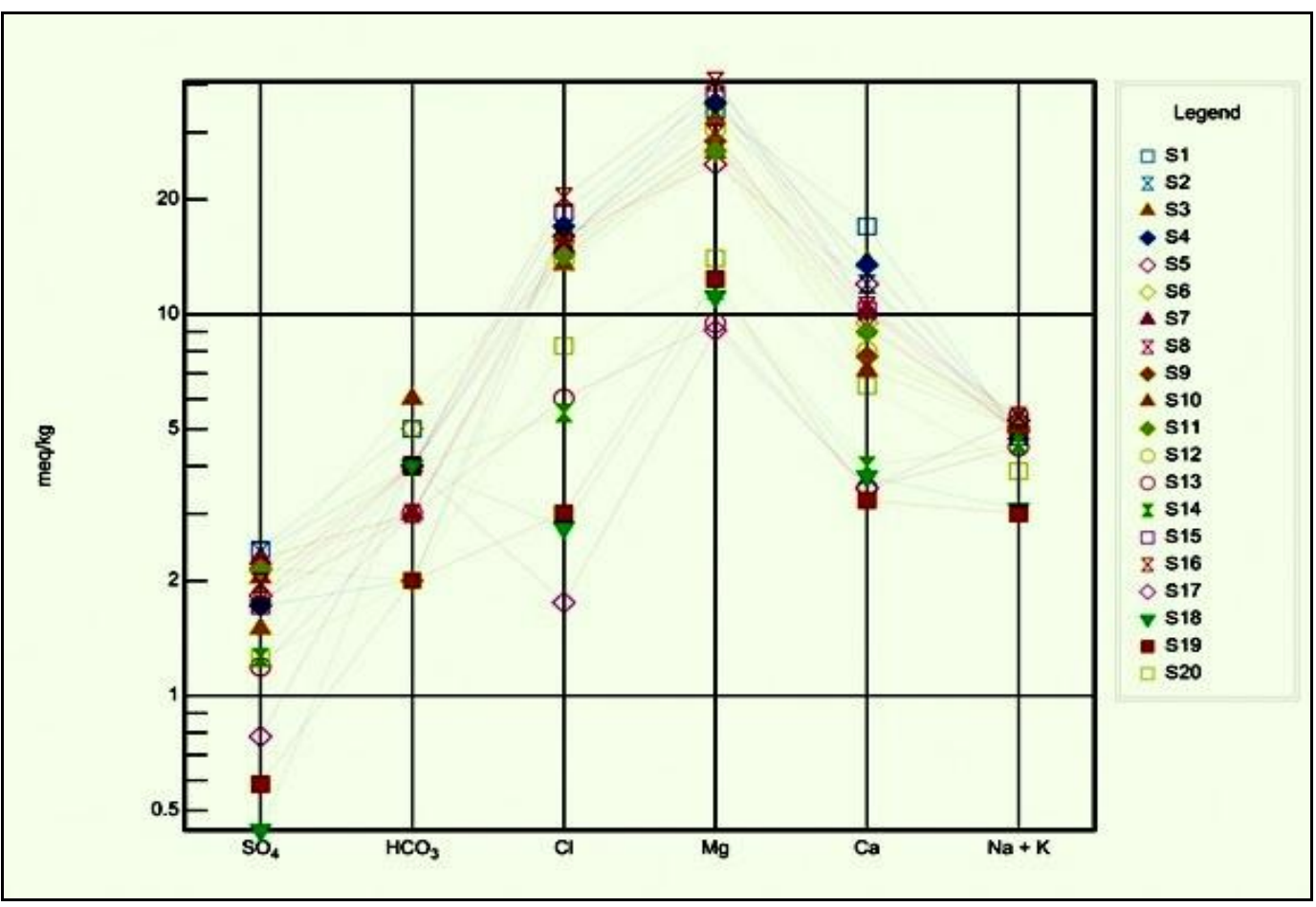

Figure 6: Schoeller Diagram of Groundwater Chemistry of the Study Area

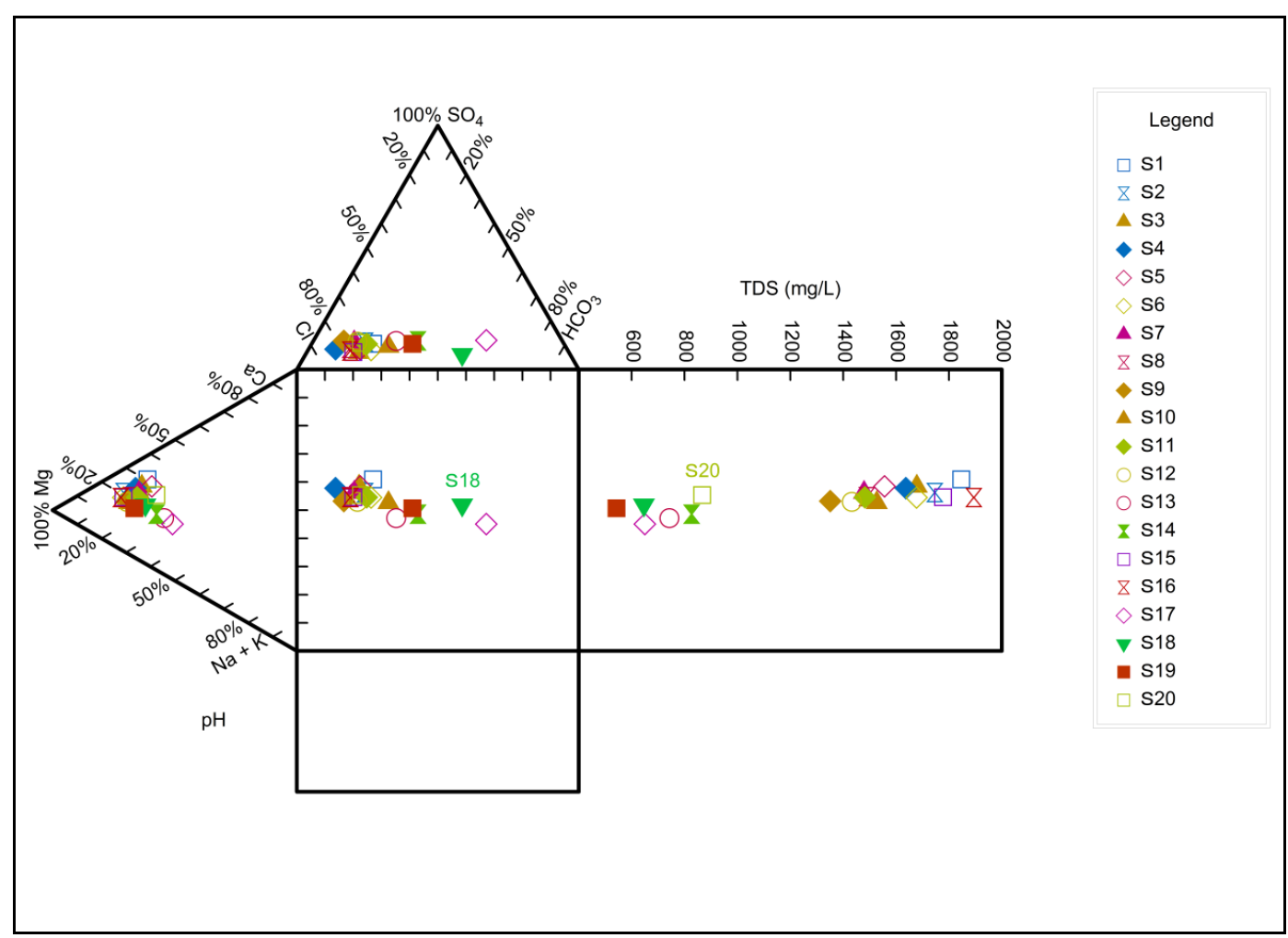

Figure 7: Durov Plot for Groundwater Parameters of the Study Area

Table 7, showed the degree of dependency and relationship between two variables using correlation coefficient. In the study, Spearman rank coefficient is used to understand the relationship between various elements, based on the ranking of the data and not absolute values. The correlation matrix prepared for the analyzed ions of the samples show the absolute correlation among EC and TDS. A 
good correlation $(\mathrm{r}=0.91-0.99)$ among TDS, $\mathrm{EC}, \mathrm{TH}, \mathrm{Cl}, \mathrm{Mg}^{2+}, \mathrm{Ca}^{2+}, \mathrm{SO}_{4}{ }^{2-}$ and $\mathrm{HCO}_{3}{ }^{-}$which indicate that TDS and EC mainly due to the presence of TH, Cl, $\mathrm{Mg}^{2+}, \mathrm{Ca}^{2+}, \mathrm{SO}_{4}{ }^{2-}$ and $\mathrm{HCO}_{3}{ }^{-}$. The results found that $\mathrm{Cl}$ is significantly correlated with $\mathrm{Ca}^{2+}$ and $\mathrm{Mg}^{2+}$, indicating the presence of chloride salts of $\mathrm{Ca}^{2+}$ and $\mathrm{Mg}^{2+}$ and $\mathrm{SO}_{4}{ }^{2-}$ is moderately correlated $(\mathrm{r}=0.61)$ with $\mathrm{Na}$, evaluating the presence of $\mathrm{Na}_{-} \mathrm{SO}_{4}{ }^{2-}$ salt. TH showed a high degree of positive correlation with $\mathrm{Mg}^{2+}(\mathrm{r}=0.98) . \mathrm{Cl}$ was moderately correlated $(r=0.57$ and 55) with $\mathrm{Na}$ and $\mathrm{K}$ respectively, indicating salt of $\mathrm{Na}-\mathrm{Cl}$ and $\mathrm{K}-\mathrm{Cl}$ is present due to coastal environmental effect. The cursory examination of the data reveals that the majority of the samples are dominated by $\mathrm{Mg}^{2+}$ hardness in comparison of $\mathrm{Ca}^{2+}$ hardness and the strong correlation $(\mathrm{r}=0.93)$ between $\mathrm{Cl}$ and $\mathrm{Mg}$ showed coastal saline water inflow along with anthropogenic activities and mineral dissolution in the study area. 
1. Table 7: Correlation matrix of chemical constituents of ground water (Spearman rank coefficient)

\begin{tabular}{|c|c|c|c|c|c|c|c|c|c|c|c|c|c|c|c|c|}
\hline & pH & EC & TDS & Acidity & Alkality & TH & $\mathrm{Ca}^{2+}$ & $\mathrm{Mg}^{2+}$ & $\mathbf{K}^{+}$ & $\mathbf{N a}^{+}$ & $\mathrm{HCO}_{3}{ }^{-}$ & $\mathrm{Cl}^{-}$ & $\mathrm{SO}_{4}{ }^{2-}$ & $\mathrm{NO}_{3}^{-}$ & $\mathrm{PO}_{4}{ }^{3-}$ & $\mathrm{Fe}$ \\
\hline EC & -0.54 & & & & & & & & & & & & & & & \\
\hline TDS & -0.54 & 0.98 & & & & & & & & & & & & & & \\
\hline Acidity & 0.06 & -0.11 & -0.12 & & & & & & & & & & & & & \\
\hline Alkalinity & -0.09 & 0.22 & 0.23 & -0.68 & & & & & & & & & & & & \\
\hline TH & -0.67 & 0.82 & 0.85 & -0.21 & 0.23 & & & & & & & & & & & \\
\hline $\mathrm{Ca}^{2+}$ & -0.71 & 0.68 & 0.65 & -0.28 & 0.22 & 0.93 & & & & & & & & & & \\
\hline $\mathbf{M g}^{2+}$ & -0.60 & 0.85 & 0.87 & -0.16 & 0.23 & 0.98 & 0.82 & & & & & & & & & \\
\hline $\mathbf{K}^{+}$ & -0.24 & 0.46 & 0.47 & -0.22 & 0.21 & 0.76 & 0.77 & 0.70 & & & & & & & & \\
\hline $\mathrm{Na}^{+}$ & -0.15 & 0.65 & 0.63 & 0.12 & 0.26 & 0.40 & 0.28 & 0.44 & 0.12 & & & & & & & \\
\hline $\mathrm{HCO}_{3}^{-}$ & -0.09 & 0.22 & 0.24 & -0.68 & 0.98 & 0.23 & 0.22 & 0.23 & 0.21 & 0.26 & & & & & & \\
\hline $\mathrm{Cl}^{-}$ & -0.70 & 0.90 & 0.92 & -0.07 & 0.18 & 0.93 & 0.83 & 0.93 & 0.55 & 0.57 & 0.18 & & & & & \\
\hline $\mathrm{SO}_{4}{ }^{2-}$ & -0.55 & 0.92 & 0.89 & -0.14 & 0.23 & 0.79 & 0.72 & 0.78 & 0.45 & 0.61 & 0.23 & 0.82 & & & & \\
\hline $\mathrm{NO}_{3}{ }^{-}$ & 0.40 & -0.65 & -0.67 & 0.37 & -0.27 & -0.71 & -0.61 & -0.72 & -0.44 & -0.28 & -0.27 & -0.67 & -0.60 & & & \\
\hline $\mathrm{PO}_{4}{ }^{3-}$ & -0.37 & 0.23 & 0.25 & -0.32 & 0.25 & 0.57 & 0.76 & 0.43 & 0.77 & -0.14 & 0.25 & 0.33 & 0.35 & -0.34 & & \\
\hline $\mathbf{F e}$ & -0.13 & 0.22 & 0.22 & 0.22 & -0.11 & 0.23 & 0.30 & 0.18 & 0.40 & -0.03 & -0.11 & 0.11 & 0.28 & -0.10 & 0.48 & \\
\hline $\mathrm{Cr}$ & -0.13 & 0.04 & 0.07 & -0.03 & 0.27 & 0.14 & 0.09 & 0.16 & 0.11 & 0.10 & 0.27 & 0.12 & 0.21 & -0.03 & -0.06 & -0.01 \\
\hline
\end{tabular}




\subsection{Temporal variation assessment of groundwater}

In the study area, the temporal variation assessment of groundwater quality is performed to analyze the groundwater quality from 2004 to 2013 and evaluated the concentration behavior of EC, TDS, TH, and Chloride (Table 8)., is represented by scattering with line graph in figure 8 .

Table 8: Average Groundwater Data in the Study Area

\begin{tabular}{|c|c|c|c|c|}
\hline \multicolumn{5}{|c|}{$\begin{array}{l}\text { Average ground water data of Amroli area, Surat } \\
\text { (SMC) }\end{array}$} \\
\hline Year & TDS & EC & TH & Chloride \\
\hline 2004 & 923 & 1442 & 179 & 164 \\
\hline 2005 & 1020 & 1593 & 203 & 210 \\
\hline 2006 & 1045 & 1632 & 239 & 259 \\
\hline 2007 & 1149 & 1789 & 262 & 277 \\
\hline 2008 & 1257 & 1964 & 287 & 303 \\
\hline 2009 & 1536 & 2404 & 310 & 339 \\
\hline 2010 & 1618 & 2528 & 375 & 380 \\
\hline 2013 & 1935 & 2647 & 489 & 438 \\
\hline
\end{tabular}

The evaluation pointed out the concentration of chemical constituents in groundwater is continuously increasing due to anthropogenic activities as well as mineral dissolution. It is important to take appropriate preventive measures to put a check on the drastic decreasing trend of groundwater abstraction rate. 
A)

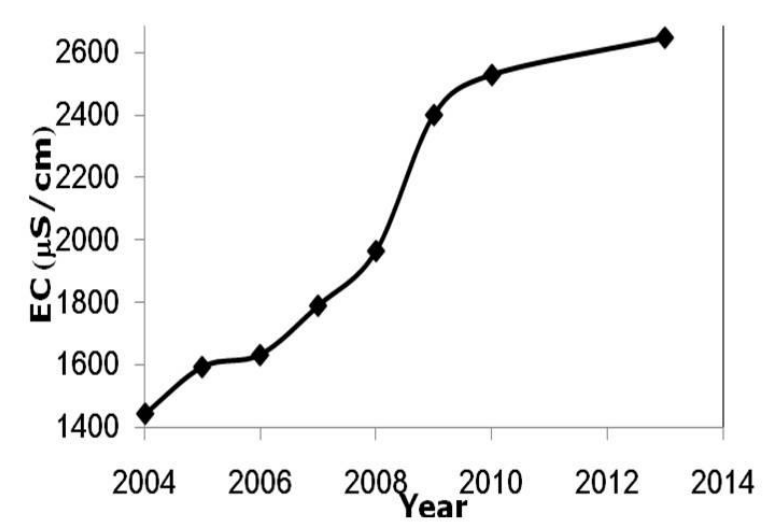

C)



B)

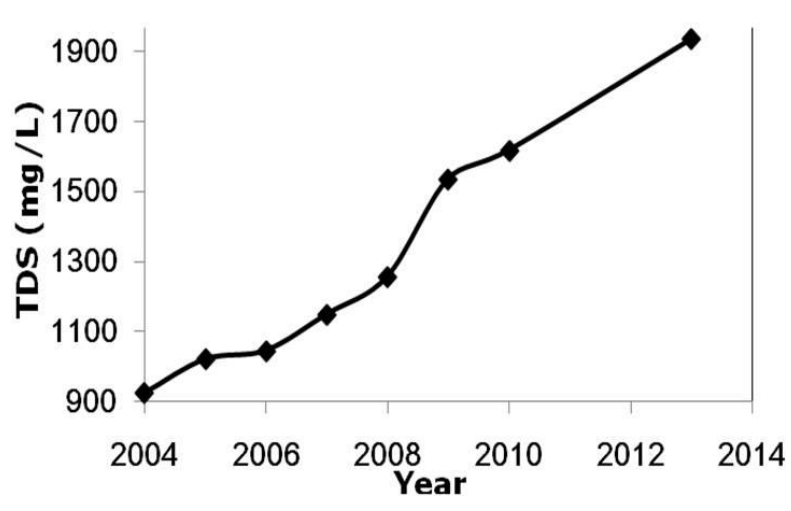

D)

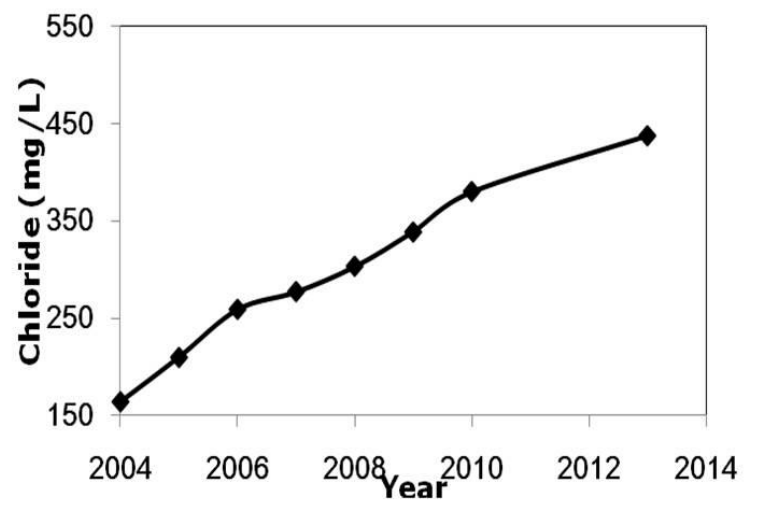

Figure 8: Temporal Variation Graphs between Average Groundwater Data Parameters and time (A) Temporal variation of Year and EC, (B) Temporal variation of Year and TDS, (C) Temporal variation of Year and TH, (D) Temporal variation of Year and Chloride

\section{Conclusion and Recommendation}

The study presented the geochemical analysis of the groundwater using the statistical approach estimating the potential quality of the groundwater resources in the Western India, Surat city. The water quality data were validated with the existing trends and the evaluation performed based on best-fitted models to classify the suitability of the ground water usages. The results clearly evaluated that the groundwater in the city is not of drinkable/potable quality, without proper treatment but fits well within categories of irrigation usages. The results found the sequence of the abundance of the major ions are in the order of $\mathrm{Cl}->\mathrm{HCO} 3->\mathrm{SO} 42->$ PO42- > NO3- and Mg2 $+>$ $\mathrm{Ca} 2+>\mathrm{Na}+>\mathrm{K}+>\mathrm{Fe}>\mathrm{Cr} 2+$ and among these the high $\mathrm{Cl}-$ content indicates the the impact of coastal environment as well as anthropogenic activities on groundwater quality. The higher $\mathrm{Mg} 2+$ content in comparison of $\mathrm{Ca} 2+$ suggested that the carbonate weathering also impacting the groundwater in the study area. To perform the geochemical evaluation of ground water quality, samples divided into different water type and result from Piper diagram showed that the water can be classified into two distinct facies viz. $\mathrm{Mg}-\mathrm{Cl}$ and $\mathrm{Mg}-\mathrm{HCO}$. The results obtained from a statistical analysis, correlation coefficient, revealed that the majority of the groundwater samples are 
dominated by $\mathrm{Mg} 2+$ hardness in comparison of $\mathrm{Ca} 2+$ hardness and strong correlation $(\mathrm{r}=0.93)$ between $\mathrm{Cl}$ and $\mathrm{Mg}$ showed the coastal saline water inflow and the presence of anthropogenic activities and mineral dissolution impacting the groundwater. The results assess the study region with high concentration of TH (Total Hardness), Chloride, and TDS, and these factors may cause severe health hazard in near future in case of using groundwater for drinking purpose without proper treatment. The study concluded that using groundwater for drinking purposed can cause many health adverse effects such as chronic physiological, so preventive measure such as water treatment should step up the study also presented the evaluation and analysis of the suitability of groundwater for potable and irrigation purposes and found the current groundwater quality is most suitable for the irrigation. SAR based classification of irrigation water indicated that all groundwater samples belong to the excellent category (Manjusree et al., 2009) and the results are confirmed with the Wilcox diagram, for sodium percentage and total concentration also showed the samples fall in excellent category for irrigation usage. Analysis based on the sodium value present in samples highlighted that the water samples belong to the safe category. Also, based on the PI values, the groundwater quality of Surat city is designated to class I (>25\%) and class II (25-75\%), that reconfirm the analysis of suitability for irrigation. The calculations of chloroalkaline Indices 1 and 2 showed that the $10 \%$ of the groundwater sample found negative and $90 \%$ found in positive ratios, which analyzed the absence of base-exchange reaction in groundwater.

The study evaluated that the groundwater in Surat city, Western India is not suitable for the potable purposes and cannot be consumed without proper treatment. Based on analysis of major water quality parameters and standards of irrigation waters the research recommends the suitability of groundwater for irrigation purposes in or around the city. Using groundwater for potable purposed will need treatment such as reverse osmosis, water softening, ion exchange and distillation to achieve water security. In the present situation, the suitable use for the groundwater is for agriculture and related sectors. The local planner can plan the right use of groundwater based on current quality parameters to attain sustainable development of Surat City. Also, the presented numerical simulation using hydrochemical data would be very helpful in predicting future mobilization of contamination (especially chloride plume) in the aquifer system.

\section{References}

Ahmed, K.M., Bhattacharya, P., Hasan, M.A., Akhter, S.H., Alam, S.M., Bhuyian, M.H., Imam, M.B., Khan, A.A. and Sracek, O., 2004. Arsenic enrichment in groundwater of the alluvial aquifers in Bangladesh: an overview. Applied Geochemistry, 19(2), pp.181-200.

Ayers, R.S. and Westcott, D.W., 1985. Water Quality for agriculture, Food and Agricultural Organisation of the United Nations, FAO Irrigation and Drainage, Paper 29, Rome, Italy.

Biswas, A., Bhattacharya, P., Mukherjee, A., Nath, B., Alexanderson, H., Kundu, A.K., Chatterjee, D. and Jacks, G., 2014. Shallow hydrostratigraphy in an arsenic affected region of Bengal Basin: Implication for targeting safe aquifers for drinking water supply. Science of the Total Environment, 485 , pp.12-22. 
Bauder, T.A., Waskom, R.M., Davis, J.G. and Sutherland, P.L., 2011. Irrigation water quality criteria. Fort Collins, CO: Colorado State University Extension.

CDP. 2008. Revised City Development Plan 2008-2013. Surat Municipal Corporation (2008) http://www.suratmunicipal.org/content/downloads/citydevelopmentplan/Surat_CDP.zip (accessed 21.08.11.)

Coetsiers, M. and Walraevens, K., 2006. Chemical characterization of the neogene aquifer, Belgium. Hydrogeology Journal, 14(8), pp.1556-1568.

Das, A. and Kumar, M., 2015. Arsenic Enrichment in the Groundwater of Diphu, Northeast India: Coupled Application of Major Ion Chemistry, Speciation Modeling, and Multivariate Statistical Techniques. CLEAN-Soil, Air, Water, 43(11), pp.1501-1513.

Das, N., Patel, A.K., Deka, G., Das, A., Sarma, K.P. and Kumar, M., 2015. Geochemical controls and future perspective of arsenic mobilization for sustainable groundwater management: A study from Northeast India. Groundwater for Sustainable Development, 1(1), pp.92-104.

Eaton, F.M., 1950. Significance of carbonate in irrigation water. Soil Science, 69 (2), 123-133.

Garrels R.M., Christ C.L., 1965, Solutions, Minerals, and Equilibria, Freeman, Cooper and Co.

Goswami, R., Rahman, M.M., Murrill, M., Sarma, K.P., Thakur, R. and Chakraborti, D., 2014. Arsenic in the groundwater of Majuli-the largest river island of the Brahmaputra: magnitude of occurrence and human exposure. Journal of Hydrology, 518, pp.354-362.

Gleick, P.H., 1993. Water in crisis: a guide to the worlds fresh water resources.

Gleick, P.H., 2000. A look at twenty-first century water resources development. Water International, 25(1), pp.127-138.

Hinrichsen, D. and Tacio, H., 2002. The coming freshwater crisis is already here. The linkages between population and water. Washington, DC: Woodrow Wilson International Center for Scholars, pp.1-26.

Kapshe, M., Kuriakose, P.N., Srivastava, G. and Surjan, A., 2013. Analysing the co-benefits: case of municipal sewage management at Surat, India. Journal of Cleaner Production, 58, pp.51-60.

Kazi, T.G., Arain, M.B., Baig, J.A., Jamali, M.K., Afridi, H.I., Jalbani, N., Sarfraz, R.A., Shah, A.Q. and Niaz, A., 2009. The correlation of arsenic levels in drinking water with the biological samples of skin disorders. Science of the Total Environment, 407(3), pp.1019-1026.

Kim, S.H., Kim, K., Ko, K.S., Kim, Y. and Lee, K.S., 2012. Co-contamination of arsenic and fluoride in the groundwater of unconsolidated aquifers under reducing environments. Chemosphere, 87(8), pp.851-856.

Kumar, P., Kumar, A., Singh, C.K., Saraswat, C., Avtar, R., Ramanathan, A.L. and Herath, S., 2016a. Hydrogeochemical Evolution and Appraisal of Groundwater Quality in Panna District, Central India. Exposure and Health, 8(1), pp.19-30.

Kumar, P., Saraswat, C., Mishra, B.K., Avtar, R., Patel, H., Patel, A., Sharma, T. and Patel, R., 2016b. Batch technique to evaluate the efficiency of different natural adsorbents for defluoridation from groundwater. Applied Water Science, pp.1-10.

Kumar, P., Tsujimura, M., Saraswat, C., Srivastava, P.K., Kumar, M. and Avtar, R., 2016c, Quantitative Analysis of Transient Intertidal Submarine Groundwater Discharge in Coastal Aquifer of Western Japan. Proceedings of the National Academy of Sciences, India Section A: Physical Sciences, pp.1-10. 
Kumar, P., Kumar, M., Ramanathan, A.L. and Tsujimura, M., 2010. Tracing the factors responsible for arsenic enrichment in groundwater of the middle Gangetic Plain, India: a source identification perspective. Environmental Geochemistry and Health, 32(2), pp.129-146.

Mahanta, C., Enmark, G., Nordborg, D., Sracek, O., Nath, B., Nickson, R.T., Herbert, R., Jacks, G., Mukherjee, A., Ramanathan, A.L. and Choudhury, R., 2015. Hydrogeochemical controls on mobilization of arsenic in groundwater of a part of Brahmaputra river floodplain, India. Journal of Hydrology: Regional Studies, 4, pp.154-171.

McArthur, J.M., Banerjee, D.M., Hudson-Edwards, K.A., Mishra, R., Purohit, R., Ravenscroft, P., Cronin, A., Howarth, R.J., Chatterjee, A., Talukder, T. and Lowry, D., 2004. Natural organic matter in sedimentary basins and its relation to arsenic in anoxic ground water: the example of West Bengal and its worldwide implications. Applied Geochemistry, 19(8), pp.1255-1293.

Mills B., 2003. Interpreting Water Analysis for Crop and Pasture. File No. FS0334, DPI's Ageny for Food and Fiber Sciences, Toowoomba.

Meliker, J.R., AvRuskin, G.A., Slotnick, M.J., Goovaerts, P., Schottenfeld, D., Jacquez, G.M. and Nriagu, J.O., 2008. Validity of spatial models of arsenic concentrations in private well water. Environmental research, 106(1), pp.42-50.

Metcalf and Eddy., 2003. Wastewater Engineering, Treatment and Reuse, 4th Edition, McGrawHill, New York.

Miller, G.W., 2006. Integrated concepts in water reuse: managing global water needs. Desalination, 187(1-3), pp.65-75.

Mukherjee, A., Saha, D., Harvey, C.F., Taylor, R.G., Ahmed, K.M. and Bhanja, S.N., 2015. Groundwater systems of the Indian sub-continent. Journal of Hydrology: Regional Studies, 4, pp.114.

Nickson, R., Sengupta, C., Mitra, P., Dave, S.N., Banerjee, A.K., Bhattacharya, A., Basu, S., Kakoti, N., Moorthy, N.S., Wasuja, M. and Kumar, M., 2007. Current knowledge on the distribution of arsenic in groundwater in five states of India. Journal of Environmental Science and Health Part A, 42(12), pp.1707-1718.

Nishanthiny, S.C., Thushyanthy, M., Barathithasan, T. and Saravanan, S., 2010. Irrigation water quality based on hydro chemical analysis, Jaffna, Sri Lanka. American-Eurasian J. Agric. \& Environ. Sci, 7(1), pp.100-102.

Pettygrove, G.S. and T. Asano., 1985. Irrigation with reclaimed municipal wastewater - a guidance manual. Lewis Publishers, Inc., Chelsea, MI, USA.

Radloff, K.A., Zheng, Y., Michael, H.A., Stute, M., Bostick, B.C., Mihajlov, I., Bounds, M., Huq, M.R., Choudhury, I., Rahman, M.W. and Schlosser, P., 2011. Arsenic migration to deep groundwater in Bangladesh influenced by adsorption and water demand. Nature geoscience, 4(11), pp.793-798.

Rupal, M., Tanushree, B. and Sukalyan, C., 2012. Quality characterization of groundwater using water quality index in Surat city, Gujarat, India. Int Res J Environ Sci, 1(4), pp.14-23.

Saraswat, C., Kumar, P. and Mishra, B.K., 2016. Assessment of stormwater runoff management practices and governance under climate change and urbanization: An analysis of Bangkok, Hanoi and Tokyo. Environmental Science \& Policy, 64, pp.101-117.

Saleh A., Al-Ruwaih F., and Shehata M., 1999. Hydrogeochemical processes operating within the main aquifers of Kuwait. J. Arid Environ. 42, 195-209.

Schoeller H., 1977. Geochemistry of groundwater, Chap. 15. In Groundwater Studies: An International Guide for Research and Practice . pp.1-18. UNESCO, Paris. 
Singh, S.K., Ghosh, A.K., Kumar, A., Kislay, K., Kumar, C., Tiwari, R.R., Parwez, R., Kumar, N. and Imam, M.D., 2014. Groundwater arsenic contamination and associated health risks in Bihar, India. International Journal of Environmental Research, 8(1), pp.49-60.

Smedley, P.L. and Kinniburgh, D.G., 2002. A review of the source, behaviour and distribution of arsenic in natural waters. Applied geochemistry, 17(5), pp.517-568.

Srivastava, S.K. and Ramanathan, A.L., 2008. Geochemical assessment of groundwater quality in vicinity of Bhalswa landfill, Delhi, India, using graphical and multivariate statistical methods. Environmental Geology, 53(7), pp.1509-1528.

Sawyer CN, McCarty PL. 1978., Chemistry for environmental engineering. Mc-Graw Hill, New York, p 532

Tanvir Hassan, S.M. 2008. Assessment of groundwater evaporation through groundwater model with spatio - temporally variable fluxes: case study of Pisoes catchment, Portugal. Enschede, ITC.

Manjusree, T.M., Joseph, S. and Thomas, J., 2009. Hydrogeochemistry and groundwater quality in the coastal sandy clay aquifers of Alappuzha district, Kerala. Journal of the Geological Society of India, 74(4), pp.459-468.

Uddin, M.K., Juraimi, A.S., Ismail, M.R., Othman, R. and Rahim, A.A., 2011. Relative salinity tolerance of warm season turfgrass species. Journal of Environmental Biology, 32(3), p.309.

Vörösmarty, C.J., Green, P., Salisbury, J. and Lammers, R.B., 2000. Global water resources: vulnerability from climate change and population growth. science, 289(5477), pp.284-288.

Wilcox, L.V., 1955. Classification and use of irrigation waters, Agric. Circ. 969, USDA, Washington D.C., pp. 19.

World Health Organization, WHO, 2004. Guidelines for drinking-water quality (Vol. 1). World Health Organization. 